\title{
OBLICZA WSPÓŁCZESNYCH MIGRACJI
}

\author{
Katarzyna Marzęda-Młynarska \\ Uniwersytet Marii Curie-Skłodowskiej w Lublinie \\ Wydział Politologii, Zakład Stosunków Międzynarodowych \\ e-mail:marzedak@wp.pl \\ Agata Wiktoria Ziętek \\ Uniwersytet Marii Curie-Skłodowskiej w Lublinie \\ Wydział Politologii, Zakład Stosunków Międzynarodowych \\ e-mail:wiktoriazietek@gmail.com
}

Ludzie migrują od zawsze. Uważa się, że prehistoryczny przodek współczesnego człowieka wyemigrował z Afryki około 40 tysięcy lat temu i zasiedlił nowe lądy i kontynenty ${ }^{1}$, co dało początek wielu cywilizacjom. Nie ulega zatem wątpliwości, że bez migracji świat wyglądałby zdecydowanie inaczej i być może inaczej potoczyłyby się także jego losy.

Migrowanie czyli przemieszczanie się stanowi element natury ludzkiej. Motywowane wieloma czynnikami, począwszy od tak nieskomplikowanych, jak zwykła ciekawość, po bardziej złożone, obejmujące kwestie polityczne, gospodarcze, kulturowe, religijne, klimatyczne, obiektywne i subiektywne, jest procesem, którego nie da się trwale wyeliminować. Nie da się bowiem zmienić natury ludzkiej i żadne bariery administracyjne czy fizyczne nie mają tu znaczenia. Oczywiście można je spowalniać, kontrolować lub kierunkować, lecz nie można ich całkowicie powstrzymać. Akceptacja tego prostego faktu stanowi punkt wyjścia do dyskusji na temat złożoności problemu migracji. Dotyczy to zarówno wielości czynników je stymulujących, jak również ich form, przejawów i skutków. Składają się na nie bowiem migracje wewnątrz państw oraz pomiędzy państwami,

1 Z poglądem tym kłócą się współczesne odkrycia, wskazujące na dużo wcześniejsze daty, co więcej wśród badaczy nie ma zgody co do pochodzenia człowieka i momentu jego pojawienia się na Ziemi. Szerzej patrz: M.A. Cremo, R.L. Thomson, Ukryta historia człowieka. Zakazana archeologia, Wydawnictwo Arche, Wrocław 1996. 
migracje dobrowolne i przymusowe, migracje w celu poprawy sytuacji ekonomicznej oraz w celu ochrony własnego życia.

Druga dekada XXI wieku bez wątpienia stoi pod znakiem migracji. Ich symbolem stał się kryzys migracyjny w Europie, będący skumulowanym efektem konfliktów na Bliskim Wschodzie i w Afryce Północnej, eksplozji demograficznej w państwach muzułmańskich (Pakistan, Afganistan, Bangladesz, Afryka Północna) i Afryki Subsaharyjskiej (Nigeria), depopulacji w Europie, biedy i ubóstwa, chaotycznej polityki migracyjnej państw europejskich i samej UE, poprawności politycznej zakrapianej ideologią, aktywizacji grup przestępczych oraz coraz łatwiejszego dostępu do informacji.

Wbrew jednak temu, co wielu może sądzić, nasilenie migracji, szczególnie tych o charakterze międzynarodowym nie rozpoczęło się w 2015 roku, ale trwa nieprzerwanie od lat 60. XX wieku. Analizy Międzynarodowej Organizacji ds. Migracji (International Organization for Migration-IOM) wskazują dobitnie, że w okresie 1960 - 2015 skala międzynarodowych migracji ulegała potrojeniu: z 77 milionów migrantów do blisko 244 milionów migrantów i nic nie wskazuje na zahamowanie tego trendu w przyszłości. ${ }^{2}$ Statystki pokazują, że co siódmy mieszkaniec globu w 2015 roku był migrantem, a więc około 1 miliarda ludzi, w tym 740 milionów stanowili tzw. wewnętrzni przesiedleńcy, a 244 miliony migranci międzynarodowi. ${ }^{3}$ Tym co może budzić zaniepokojenie jest rosnąca liczba osób zmuszonych do migracji. W samym tylko 2015 roku około 65,3 miliona osób musiało opuścić swoje domy, głównie w wyniku konfliktów zbrojnych, co było absolutnym rekordem od momentu prowadzenia statystyk. ${ }^{4}$ Wśród nich prawie 22,5 miliona stanowili uchodźcy, z czego ponad połowa to osoby poniżej 18 roku życia ${ }^{5}$. Od 2015 roku w świadomości wielu mieszkańców Europy utrwala się obraz kontynentu, obleganego przez uchodźców. Należy jednak podkreślić, że na 10 uchodźców aż 9 znajduje schronienie w państwach nieeuropejskich ${ }^{6}$

Badania wskazują, że migracje były, są i będą nieodłącznym elementem rzeczywistości i nie ma sensu z tym faktem dyskutować. Co innego w przypadku ich źródeł i skutków. Tu zdecydowanie otwiera się szerokie pole do dyskusji. A ponieważ współczesne procesy migracyjne mają różne oblicza i są analizowane z różnych punktów widzenia, ich osią powinny być dwa problemy. Po pierwsze, jak przeciwdziałać przymusowym migracjom i ograniczyć towarzyszące im negatywne zjawiska, po drugie, jak wykorzystać ten ludzki strumień

2 IOM, Global migration trends, URL: http://gmdac.iom.int/global-migration-trends-factsheet, [dostęp 11.08.2017]; Migration Policy Institute, International Migration Statistics, URL: http://www. migrationpolicy.org/programs/data-hub/international-migration-statistics, [dostęp, 11.08.2017].

3 IOM, Global migration trends, op. cit.

${ }^{4}$ Ibidem.

5 UN Refugee Agency, URL: http://www.unhcr.org/uk/figures-at-a-glance.html [dostęp, 10.10.207].

6 Refugee Council, URL:https://www.refugeecouncil.org.uk/latest/news/5000_top_20_facts_ about_refugees_and_people_seeking_asylum, [dostęp, 10.10.2017]. 
z pożytkiem dla państw przyjmujących i wysyłających. Powszechnie uważa się, że migracje są szansą zarówno dla państw przyjmujących, wysyłających oraz samych migrantów, pod warunkiem, że zostaną spełnione określone warunki, w tym wprowadzenie adekwatnej do potrzeb, polityki imigracyjne oraz wola do międzynarodowej współpracy.

Niniejszy tom stanowi głos w toczącej się dyskusji na temat współczesnych migracji. Jego idea wyrosła $\mathrm{z}$ obserwacji wydarzeń związanych z masowym napływem migrantów do Europy w 2015 roku. Narosłe wokół niego kontrowersje, zmieniająca się polityka państw i postawy społeczne, a także wielość niesprawdzonych informacji, skłoniły redaktorów niniejszego tomu do głębszej analizy tego fenomenu. Do uczestnictwa w publikacji zaproszono badaczy reprezentujących różne ośrodki naukowe i różne spojrzenia na problem migracji, a zawarte w nim artykuły pokazują jego złożoność, obalając przy tym szereg mitów i nieuprawnionych sądów. Wprawdzie na ten temat migracji napisano wiele książek i zorganizowano wiele konferencji naukowych, jednak wciąż rzeczywistość międzynarodowa, jak pisał Józef Kukułka, szybciej się komplikuje niż dojrzewa, tym samy procesy migracyjne ciągle zaskakują badaczy, ukazując coraz nowe oblicza.

Tom otwiera artykuł Agnieszki Piekutowskiej i Elżbiety Kużelewskiej pt. Migracje międzynarodowe $w$ XXI wieku. Nowe trendy $i$ wyzwania, w którym autorki dowodzą, że presja migracyjna jest trwałą tendencją współczesnego świata i w przyszłości będzie narastać, a jej stymulatorem - paradoksalnie - będzie poprawa sytuacji gospodarczej w państwach najsłabiej rozwiniętych. Autorki tym samym przychylają się do prezentowanego przez wielu ekspertów poglądu, że współcześnie migrują ci, których na to stać. Agata W. Ziętek w artykule pt. Sekurytyzacja migracji w bezpieczeństwie kulturowym Europy zwraca uwagę na zjawisko 're-konstruowania' problemu migracji w europejskiej przestrzeni publicznej, którego efektem jest wzrost postaw ambiwalentnych, przejawiających się zarówno we współczuciu dla migrantów, jak i rosnącej niechęci do nich. Zdaniem autorki, to czy imigracja do Europy będzie traktowana jako zagrożenie egzystencjalne (sekurytyzacja), czy jako problem, którym powinna się zająć „normalna” polityka (desekurytyzacja) zależy w dużej mierze od stopnia podatności społeczeństw na określony typ narracji. W artykule pt. The 2015 Migration Crisis in the European Union as a Non-Traditional Security Challenge Katarzyna Marzęda-Młynarska ujmuje problem migracji z perspektywy koncepcji niestandardowych problemów bezpieczeństwa, dowodząc, że im bardziej kryzys migracyjny był przedstawiany jako zagrożenie bezpieczeństwa, z tym większym zainteresowaniem i wolą współpracy ze strony państw członkowskich UE się spotykał. Magdalena Perkowska w artykule pt. Nielegalna migracja $w$ Europie - aspekty prawne i kryminologiczne koncentruje swoją analizę na zjawisku nielegalnej migracji. Opierając się na danych statystycznych wskazujących, że skala nielegalnej migracji w Europie stale rośnie, podobnie jak liczba osób przekraczających nielegalnie granicę zewnętrzną UE oraz przebywających nielegalnie na jej terytorium, Autorka dochodzi do wniosku, że rozwiązanie tego problemu leży przede wszystkim po stronie państw 
wysyłających. Artykuł pt. Les facteurs et l'importance de la migration dans l'espace euro-maghrébin Katarzyny Stachurskiej-Szczesiak podejmuje ważny temat migracji z państw Afryki Północnej do Europy. Autorka weryfikuje w nim hipotezę, zgodnie z którą, bliskość geograficzna i kontekst historyczny wpływają na charakter migracji euro-maghrebskiej i jej rolę w stabilizowaniu południowych granic UE. Nieco inną perspektywę prezentuje artykuł Agnieszki Nitszke pt. Niemieckie ugrupowania polityczne wobec kryzysu uchodźczego, w którym autorka analizuje stanowisko głównych partii politycznych w Niemczech wobec kryzysu migracyjnego i kwestii imigracji dowodząc, że w obliczu kryzysu migracyjnego niemiecka scena polityczna nie tylko nie doznała wstrząsu, ale także poszczególne partie parlamentarne nie zrewidowały zasadniczo swoich poglądów w odniesieniu do polityki migracyjnej. Dwa ostatnie artykuły - Magdaleny El Ghamari pt. Poczatek destabilizacji regionu Bliskiego Wschodu czyli operacja „Iracka Wolność" - próba diagnozy konfliktu militarnego i jego skutki oraz Davida Jervisa pt. „No” to No-Fly Zones in Syria odsłaniają kulisy współczesnego kryzysu migracyjnego. Magdalena El Ghamari upatruje źródła współczesnego kryzysu migracyjnego w niepowodzeniu operacji militarnych, podejmowanych przez zewnętrznych interwentów, w tym przede wszystkim USA, w państwach Bliskiego Wschodu i Afryki Północnej. Zdaniem autorki operacje te nie tylko nie osiągnęły założonych celów politycznych (operacja Iracka Wolność), lecz wręcz przeciwnie, stały się stymulatorem szeregu negatywnych zjawisk, skutkujących dramatycznym pogorszeniem sytuacji ludności cywilnej, czego konsekwencją był masowy exodus. Z kolei David Jervis dowodzi, że promowane przez niektórych polityków, szczególnie z USA, inicjatywy stworzenia w Syrii stref bezpieczeństwa lub stref zakazu lotów, nie tylko nie przyczynią się do poprawy sytuacji ludności cywilnej, lecz wręcz przeciwnie, mogą stanowić dla niej śmiertelne zagrożenie. 